\title{
Controlling the Market Power of Performing Rights Societies: an Administrative Substitute for Antitrust Regulation
}

The public performing rights ${ }^{1}$ to most copyrighted musical works in this country are licensed by two major performing rights societiesthe American Society of Composers, Authors, and Publishers (ASCAP) and Broadcast Music, Inc. (BMD). ${ }^{2}$ Individual copyright owners assign these organizations the right to hicense nondramatic public performances of their musical compositions. Performing rights societies im turn issue blanket licenses entitling licensees to perform any and all works in the societies' repertories. The fees for sucl blanket licenses are generally based upon a percentage of the licensees' gross receipts rather than upon the popularity of works performed or number of performances rendered. ${ }^{3}$

Because ASCAP and BMI together maintam a virtual monopoly over the licensing of musical performance rights in this country, their operations and practices frequently have been challenged under United States antitrust laws. In particular, the societies' practice of issuing blanket licenses has been vulnerable to charges that it eliminates price coinpetition between individual compositions, since hicensees are entitled to perform any work in the societies' repertories for a fee not based on actual use. Both ASCAP and BMI have been the targets of numerous governmental and private antitrust actions. As a result, both organizations are subject to substantial regulation pursuant to judicially enforced consent decrees and are prohibited from issuing blanket hicenses to certain groups of users. Most recently, in Buffalo Broadcasting Co. v. $A S C A P,{ }^{4}$ both organizations were enjoined from issumg blanket performance licenses to local television broadcasters.

1. The exclusive right to publicly perform copyrighted musical works is provided for by 17 U.S.C. § 106(4) (1982).

2. ASCAP and BMI together handle the bulk of nondramatic liceusing transactions in this country. ASCAP, the larger of the two organizations, is an unincorporated membership association consisting of approximately 8,000 music publishing compamies and 21,000 writers, composers and lyricists; it boasts a repertory of over 3 million compositions. BMI is a nouprofit corporation affliated with approximately 22,000 publishers and 38,000 writers, with about 1 million compositions in its repertory. Buffalo Broadcasting Co. v. ASCAP, 546 F. Supp. 274, 277 (S.D.N.Y. 1982).

3. S. Shemel \& M. Krasilovsky, This BusIness of MUSIC 163 (rev. ed. 1977). See also infra note 15.

4. 546 F. Supp. 274 (S.D.N.Y. 1982). 
This Comment argues that the regulation of performing rights societies through the enforcement of antitrust laws is inappropriate and inefficient. Such regulation would be better achieved by the establishment of an administrative agency to oversee those societies' practices. Part I of this Comment outlines briefly the history, development, and licensing practices of ASCAP and BMI. Part II discusses the advantages of the blanket licensing of performance rights in copyrighted musical works. Part III describes the various public and private antitrust actions that have been brought agaimst ASCAP and BMI to guard agamst abuses of narket power under blanket licensing, and the resulting limitations that have been imposed upon their practices. Part IV argues that antitrust laws are fundamentally ineffective im preventimg performing rights societies from exploiting their monopoly powers. In particular, this Comment will argue that the goal of antitrust enforceinent-proinoting price competition among musical coinpositions-is unrealistic and quixotic in a market where price seldoin influences a user's selection of music. Finally, Part V exammes the administrative agencies that Great Britain and West Germany have established to oversee the practices of performing rights societies. This Comment proposes that the United States estabhish a comparable agency to effectively regulate performing rights licensing and curb the monopolistic practices of performing riglits societies.

\section{I \\ Performing Rights Societies}

Coinposers who have obtamed copyright protection for their musical compositions enjoy certaim exclusive rights under the copyright laws. ${ }^{5}$ Among these is the right to "perform the copyrighted work publicly" or to authorize another's public performance of the composition. ${ }^{6}$ Performance rights have been granted to copyright holders since 1897, but for many years composers' revenues were comprised primarily of royalties froin the sale of sheet music rather than from public performances of the work. With the advent of the phonograpli and the rise of the broadcast media, however, performance rights assumed primary importance for copyright owners. ${ }^{8}$

5. 17 U.S.C. $\S 106$ (1982). These rights include the exclusive right to reproduce the copyrighted work, to prepare derivative works, to distribute copies or phonorecords to the public, to perform the work publicly, and to display the work publicly.

6. 17 U.S.C. \& 106(4) (1982).

7. Act of Jan. 6, 1897, ch. 4, 29 Stat. 481 (codified as amended at 17 U.S.C. § 106(4) (1982)).

8. See B. Kaplan \& R. Brown, Cases on Copyright 430 (1960). Public performances are currently the major source of revenue in the music industry, with ASCAP alone generating well over $\$ 125$ million in royalties annually. A. LATMAN \& R. GORMAN, COPYRIGHT FOR THE EiGHTies 455 (1981). 
The ephemeral nature of public performances made it difficult for copyright owners to detect unauthorized performances of their works. At the same time, potential licensees often found it difficult to locate the author of a particular work to negotiate a license authorizing performances. To resolve the related problems of enforcement and licensing of performance rights, a group of prominent American coinposers banded together in 1914 to form ASCAP. 9 Thus, ASCAP was designed as a clearimghouse for the licensing and enforcement of statutorily guaranteed performance rights.

Composers, lyricists, and publishers become members of ASCAP by assigning the organization the nonexclusive right ${ }^{10}$ to license nondrainatic public performances ${ }^{11}$ of their works. ASCAP in turn grants hicenses to networks, local television and radio stations, theaters, bars, restaurants, and other users of copyrighted music. ${ }^{12}$ ASCAP offers licenses to these users on either a blanket or per-program basis. Blanket licenses entitle licensees to perform any work in ASCAP's repertory for the duration of the license-generally one year. Fees for such licenses depend on the nature of the licensee's business, although all similarly situated licensees must be treated equally. ${ }^{13}$ Generally, however, fees are a flat rate or are based upon a fixed percentage of some measure of the licensee's gross revenues. ${ }^{14}$ Fees thus do not reflect the actual number of such works used or the number of performances rendered. ${ }^{15}$ Per-program licenses, like blanket licenses, enable the licensee

9. A. Latman \& R. Gorman, supra note 8, at 419. See also 2 Nimmer on Copyright $\S 8.19$, at 8-238 (1983).

10. ASCAP is prohibited from obtaining an exclusive right to license performance rights. Umited States v. ASCAP, 1950-1951 Trade Cas. (CCH) \ 62,595, at 63,752 (S.D.N.Y. 1950).

11. ASCAP and BMI acquire and license only small or nondramatic performing rights as distinguished from grand or dramatic performing rights in copyrighted music. A dramatic performance is defined as "a performance of a musical composition in which there is a definite plot depicted by action and where the performance of the musical composition is woven into and carries forward the plot and its accompanying action." ASCAP Television License, quoted in $\mathbf{S}$. SHemel \& M. KRASILovSKY, supra note 3, at 177. Dramatic or grand performances of copyrighted music are likely to be less frequent and easier for the copyright owner to license directly.

12. Buffalo Broadcasting Co. v. ASCAP, 546 F. Supp. 274, 277 (S.D.N.Y. 1982).

13. See infra note 57 and accompanying text.

14. For example, the fee for radio stations is slightly less than two percent of the stations' adjusted advertising reveuues. S. SHEMEI \& M. KRASiLovSKY, supra note 3, at 163. Local television broadcasters are also charged a percentage of their adjusted advertising revenues. Fees for other users are based upon different measures of the users' gross receipts. For bars and nightclubs, fees vary depending on drinking prices, seating capacity, and admission cliarges; for hotels and motels, fees vary depending on entertainment expenses; and for concert halls, fees vary depending on admission prices and seating capacity. While most fees are based upon a percentage of gross receipts, some users are charged flat fees. For example, each of the three inajor television networks negotiates flat license fees with both organizations, largely because the parties involved have been unable to agree on accounting procedures for computing the networks' incomes. A. LATMAN \& R. GORMAN, supra note 8, at 455.

15. S. SHEMEL \& M. KRASILOvSKY, supra note 3, at 163. Even for network fees based upon 
to use any work in the society's repertory. While fee percentages for per-program hicenses are generally higher than those for blanket licenses, such a percentage is exacted from the revenues for only those programs that inake use of ASCAP inusic. ${ }^{16}$

Fees collected by ASCAP become part of a single common fund that is divided equally between publishers' and writers' member groups. ${ }^{17}$ These groups in turn distribute royalty payments to imdividual neinbers, based either on the number of performances of the member's works or on a complex "spreading of payments" formula. ${ }^{18}$

Until 1939, ASCAP was the sole American performing riglits society. In 1939, broadcast station owners formed BMI to counter what they perceived to be ASCAP's exorbitant licensing fees and unacceptable practices. ${ }^{19}$ ASCAP and BMI remain the leading performing rights societies in the United States. ${ }^{20}$

flat rates, the amount paid for blanket licenses does not vary with the quantity or quality of music each network chooses to use.

16. Buffalo Broadcasting Co. v. ASCAP, 546 F. Supp. 274, 288-89 (S.D.N.Y. 1982).

17. S. SHEMEL \& M. KRASILOVSKY, supra note 3, at 163.

18. Id. at 168. The blanket licensing revenues collected by ASCAP are distributed to individual copyright owners according either to a credit system which accounts for the number and type of performances of each composition (for composers and publishers) or to a more coinplicated credit formula which also accounts for the performance history of the work (an option available only to composers). Id. at 168-70. Under either formulation, special credit value is grantcd for some purposes to certain "qualified works" which have accumulatcd a certaim number of feature performances. Id. at 170-71. BMI's blanket licensing revenues are distributed under similar formulas with one exception: BMI members are granted additional compensation once their composition's cumulative performances exceed a specified level. Id. at 171-73. In both cases, the distribution of revenues is conducted pursuant to each organization's nonitoring of licensees' performances by such devices as taping television broadcasts, examining radio station logs and checking the programs of nonbroadcast licensees. Since it would not be feasible to attempt to momitor all licensees' performances, each organization surveys samples froin which estimates of total national performances are derived. Id. at 165-66; Note, Blanket Licensing: The Clash Between Copyright Protection and the Sherman Act, 55 Notre Dame LAw. 729, 730 n.12 (1980) [heremafter cited as Note, Blanket Licensing]; Note, CBS v. ASCAP: Performing Rights Societies and the Per Se Rule, 87 YALE L.J. 783, 787 n.27 (1978) [hereinafter cited as Note, Performing Rights Societies].

Each organization also actively polices the performances of nonlicensees in order to detect unauthorized public performances of their members' works and initiate infrimgement proceedings when appropriate. For antitrust analysis purposes, both organizations have been treated as identical by the courts. See, e.g., CBS v. ASCAP, 562 F.2d 130, 132 n.1 (2d Cir. 1977), rev'd sub nom. BMI v. CBS, 441 U.S. 1 (1979).

19. A. LATMAN \& R. GoRman, supra note 8, at 455-56; see also S. SHEMEl \& M. KRASILovSKY, supra note 3 , at 163 .

20. A number of smaller, privately owned performing rights organizations exist which also license public performances of nusic. The most important of these is the Society of European Stage Authors and Composers, Inc. (SESAC), containing approximately 300 publisher and several hundred writer affiliates. Its operations are similar to those of the two larger organizations. S. SHEMEL \& M. KRASILOVSKY, supra note 3, at 164-65. 
II

The Necessity and Advantages of Blanket LICENSING

\section{A. Reduced Transaction Costs}

The primary value of having a single organization license the bulk of inusic performing rights under a blanket scheme is that such an organization can substantially reduce transaction costs. Individually licensing performance rights for millions of unusical compositions in separate transactions between thousands of copyright owners and music users would engender enormous transaction costs. These costs would be generated by the difficulties and complexities associated with the identification and location of individual copyright owners, the exchange of information about prices and performance opportunities for each composition, and the negotiation of separate hicensing contracts before a composition could be performed. These transaction costs may often in fact be greater in amount than the actual license fees involved in such transactions. Taken collectively, the cost of individual transactions becomes staggermg because of the sheer nuniber of transactions that would be necessary. It has been estimated that there are now over one billion licensed performances of ASCAP music annually. ${ }^{21}$

\section{Identification Costs}

Potential licensees of a given musical work may find it difficult to identify and locate the copyright owner who can authorize public performances. These difficulties are coinpounded by the fact that most users wish to license performance rights from inany copyright owners. As a result, many such users (especially proprietors of small establishments) might decide that the costs associated with obtaining a license would outweigh the benefits to be gained from the transaction. To avoid wasting inoney and effort, these users might refrain from performing certain works altogether or might resort to doing so illegally. A general clearing agency handling a large selection of inusic eliminates the chaos and expense associated with individual licensing. Users need only approach ASCAP or BMI to negotiate licenses for all the inusic they wish to perform. ${ }^{22}$

\section{Information Costs}

Without a central agency, individual negotiations for music rights would be coinphicated by the expense and difficulty of obtaining the

21. Note, Performing Rights Societies, supra note 18, at 786 (citing J. Dean, The ASCAP Survey: Its Design and Objectives (1963) (unpublished pamphlet)).

22. See S. Shemel \& M. KRAsilovsky, supra note 3, at 168. 
information necessary to negotiate a price for a given performance right. Because the value of music performance rights is largely a function of the performance itself and therefore varies according to audience size, type of use, and number of performances rendered, the parties must have access to such information im order to negotiate prices. Since most licenses are negotiated before a performance is actually rendered, composers and users are forced to estimate the price and value of their performance rights. These estimates are based upon little more than generalized information concerning a licensee's use of $\mathrm{nu}$ sic, the parties' subjective notions of a composition's "worth," and premature indications of its popularity. The difficulty of assessing performance variables and pricmg performing rights based on speculative information and the disagreements that would inevitably arise in the course of licensing negotiations would substantially add to the costs of individual licensing transactions. Even if the parties were to base their negotiations on prices charged for similar performances, information costs would still be generated as such prices would vary according to the popularity of a particular composition. Again, the number of sucli assessments and transactions would make the imdividual licensing of inusic performance rights prohibitively expensive. ${ }^{23}$

In contrast, the blanket hicense circumvents the difficulties and expense associated with individual licensing transactions. It provides an efficient system for determining the value and price of inusic performance rights based upon the benefit actually conferred by the licensed music. The price of the blanket license is measured by a percentage of

23. Proponents of source licensing have submitted that its use in licensing motion picture theatrical performing rights pursuant to the court's decision in Alden-Rochelle, lnc. v. ASCAP, 80 F. Supp. 888 (S.D.N.Y. 1948), indicates that copyright owners can estimate the value of their performing rights without substantial difficulty. While the prices for synchronization and theatrical performing rights licenses are considerably higher than those for synchronization rights hicenses only, Cirace, CBS v. ASCAP: An Economic Analysis of a Political Problcm, 47 FordHAM L. REv. 277, $295 \mathrm{n} .114$ (1978) (indicating that owners and producers recognize that performing rights have some value), there is no indication that the prices set for theatrical performance rights are based upon anything more than speculation and conjecture.

Although the price of synchronization rights would probably be zero in many instances if it were not for "nuisance value," see id., the time and negotiations involved in synchronization rights and threatrical synchronization and performance rights transactions are brief and uncoinplicated, Buffalo Broadcasting Co. v. ASCAP, 546 F. Supp. 274, 284 n.22 (S.D.N.Y. 1982). This suggests that, apart from the futility of such efforts, copyright owners and music users do not even attempt to carefully assess future performances and assign values to performance rights based upon such estimates; but price such rights according to speculative notions of a performance's value in a given inedium. In CBS v. ASCAP, 400 F. Supp. 737, 763 n.13 (S.D.N.Y. 1975), rev'd, 562 F.2d 130 (2d Cir. 1977), rev'd sub nom. BM1 v. CBS, 441 U.S. 1 (1979), the district court noted that "the increased complexity of the performing rights transaction amounts to asking the producer about the nature of the intended use and passing on the information to the pubhisher." This suggests that theatrical performance rights are priced according to the same speculative processes that govern the valuation of synchronization rights. 
the gross revenues of the licensee, such that the compensation remitted by the user is based roughly on the size of the audience actually listening to the performance. ${ }^{24}$ Different categories of users are assessed different percentages of revenues as licensing fees. ${ }^{25}$ Additionally, the fees ASCAP collects for its blanket licenses are distributed among members based on a formula ${ }^{26}$ that accounts for, among other things, the type of use made of the composition and the number of times it was performed. ${ }^{27}$ An efficient system of blanket licensing where the compensation paid by users and received by copyright owners is based on an objective measure of the value of public performances thus reduces the information costs associated with imdividual licensing. ${ }^{28}$

\section{Transaction Time Costs}

Finally, in addition to eliminating the costs of separate licensing negotiations, the blanket license eliminates the transaction costs associated with the time consumed by sucli negotiations or coinparable licensing processes. For example, inany users, imcludimg concert promoters, mightclub owners, and broadcasters carrying "live" programming, do not know in advance which compositions are to be performed. ${ }^{29}$ These users cannot rely upon prior authorization from individual copyright owners to preclude possible infrimgements, but instead require the access to entire repertories that blanket licenses provide. Moreover, the blanket license grants imstant access to new and currently popular compositions that enter a society's repertory over the term of the license, thereby obviating time-consuming licensing transactions. Many users place substantial economic value on the ability to perform any music im the society's repertory at a moment's notice and on the avoidance of the time lag inherent in licensing negotiations.

24. The compensation is also paid by the actual user of the performing right rather than the producer of the feature, as would be the case under source licensing. This fact is especially significant where a producer hopes to release his product in a variety of media (e.g., theaters, network television, cable and syndicated television). The composer would be forced to guess in which Inedium his production would appear as well as to estimate the variables of each performance in setting a simgle price for the performing right to his composition. This inay result in a producer's licensing a performing right for a medium in which his motion picture may never appear.

25. For example, all-news or all-talk radio stations are charged a lower percentage of their advertising revenues for their blanket hicenses because their use of inusic differs from that of other radio stations. See also supra note 14.

26. Members have challenged ASCAP's royalty distribution procedures based on perceived imequities. See, e.g., Umited States v. ASCAP, 442 F.2d 601 (2d Cir. 1971).

27. See supra note 18.

28. BMI v. Moor-Law, Inc., 527 F. Supp. 758, 767 (D. Del. 1982).

29. Id. at 763 . 


\section{B. Reduced Copyright Enforccment Costs}

Apart from reducing the transaction costs associated with individual hicensing negotiations, the blanket license substantially reduces the costs of protecting a copyright owner's statutory rights froin infringeinent. Aside from the transitory nature of unauthorized performances of copyrighted music, two economic characteristics make their detection especially difficult and costly. Potential infringers unay perform a copyrighted composition without leaving anything less for others to use. $^{30}$ Once the musical composition has been created, the inarginal cost of additional use (i.e., of performances) is zero. Moreover, it is difficult for a copyright owner to exclude nonpaying users froin performing his colnposition. ${ }^{31}$ Once a work becomes known or distributed, it is difficult to prevent others from performing it. In both cases, the copyright owner's inability to control access to his perforinance right reduces the unauthorized user's risk of being detected. ${ }^{32}$ It would be prohibitively expensive for an individual copyright owner to nonitor the activities of all users not authorized to perforn his work in order to guard agaimst infringeinents.

A performing rights organization like ASCAP or BMI can accomplish this policing function much more efficiently than individual copyright owners acting independently. Its administrative apparatus consolidates the otherwise duplicative efforts of individual copyright owners, each unonitoring the same user, into one effort that polices performances of all the compositions in its repertory. Because they offer performance rights under blanket licenses, ASCAP and BMI are able to further reduce inonitoring costs by focusing on the activities of only those users not holding ASCAP or BMI licenses. ${ }^{33}$ By coinprehensively inonitorimg nonlicensees for such infringeinents, performing rights organizations like ASCAP and BMI operate to discourage unauthorized performances of copyrighted music. ${ }^{34}$

30. $I d$.

31. Id.

32. In this way, music performing rights exhibit the salient characteristics of what economists refer to as "public goods."

33. While ASCAP also monitors the performances of its licensees to facilitate its distribution of royalties, it can often rely upon diaries or other forms of self-monitoring for such purposes. Because licensees operate under a blanket bicense, there is little incentive for such users to lie about their use of music. The cost of momitoring users is consequently insubstantial.

34. Proponents of per-piece licensing have suggested that, at least for broadcast licensees, the surveys ASCAP already conducts for purposes of royalty distributions could also serve to police infringements. However, policing per-piece licensees to detect unauthorized performances would still involve additional costs. In BMI v. CBS, 441 U.S. 1, 21 (1979), the Supreme Court noted that "even for television network licenses, ASCAP reduces costs absolutely by creating a blanket license that . . obviates the need for closely momitoring the networks to see that they do not use more than they pay for." It is unlikely that ASCAP could rely upon the broadcasters' records it uses for royalty distribution purposes if per-piece or per-program licensing became widespread. 
Performing rights societies and blanket licenses allow copyright owners to take advantage of economies of scale in performance rights licensing and to spread identical transaction and enforcement costs over a large group for the inutual benefit of owners and users. Both users and copyright owners are also spared the difficult task of setting prices for different performances, with users obtaining "unplanned, rapid, and indemnified access" to a wide range of compositions. ${ }^{35}$ In light of the prohibitive transaction and enforcement costs involved in individual licensing, the bulk marketing of inusic performance rights by a single organization would seem crucial to their exploitation. ${ }^{36}$

\section{Balanced Bargaining Power of User and Copyright Owner}

In addition to eliminating the transaction and enforcement costs that would otherwise substantially hinder the efficient exploitation of statutory performance rights, performing rights organizations neutralize the bargaining leverage many users would otherwise exert over individual composers. In particular, the blanket license provides the coinposer with some inarket leverage against the monopsony power ${ }^{37}$ of the major licensees from whom he derives a substantial portion of his royalties. Without ASCAP and BMI, television networks could exploit their superior inarket positions vis-a-vis individual composers, taking advantage of the intense competition among composers desiring that their works be performed on network tclevision. ${ }^{38}$ By joining a collective organization that blanket licenses music performance

Rather, ASCAP would have to directly monitor licensees' as well as nonlicensees' performances to detect unauthorized performances of its music, incurring additional costs. Moreover, it would have to monitor all non-television network licensees' performances instead of relying upon estimates drawn from sample surveys (as it does for royalty distribution purposes), again increasing its detection costs.

35. Id. at 20.

36. Other litigants have repeatedly asked the courts to require ASCAP to issue per-piece hicenses such that licensees' fees would be directly related to their actual use of music. See, e.g., United States v. ASCAP (In re Application of NBC), 1971 Trade Cas. (CCH) I 73,491 (S.D.N.Y. 1970). Although a per-piece licensing system would not require users to locate individual composers, it would not eliminate the transaction cost justification for blanket kicensing, for ASCAP would still be burdened with having to exchange information about prices and performance opportunities for each composition, and would still incur substantial costs in policing licensees for performances not authorized by the per-piece licenses.

The marketing advantages of blanket licensing have been recognized by American courts even in those decisions that have challenged the legality of blanket licensing under antitrust laws. See infra note 80 and text accompanying notes 59-60. These advantages have even been acknowledged by challengers to blanket hicensing. In $C B S$ v. ASCAP, CBS alleged in its complaint that direct licensing of performance rights was entirely infeasible since any attempt " to acquire such a large body of rights from [mdividual copyright proprietors] . . . would be wholly impracticable." " 400 F. Supp. at 745.

37. The term nonopsony power refers to the power to demand unreasonable terms which concentrated buyers in a given market can exploit vis-a-vis sellers.

38. 400 F. Supp. at 767. 
rights, ${ }^{39}$ an individual composer can counterbalance such market power to assure receipt of fair compensation. ${ }^{40}$

Even in a market where blanket hicensing has been barred by law, economic necessity will encourage cartelization to approximate the marketing and bargaining advantages of performing rights organizations. The Harry Fox Agency, ${ }^{41}$ which represents virtually every major music publisher ${ }^{42}$ in the licensing of television synchronization rights ${ }^{43}$ and theatrical synchronization and performance rights, illustrates the economic advantages of performing rights societies. The Fox Agency is not a blanket licensing society but an agent for the entire industry, and has not been subject to the same antitrust law challenges as ASCAP and BMI. Potential users of synchronization or theatrical performance rights are spared the costs of contacting and negotiating with mdividual copyright owners and need only contact the Fox Agency to license such rights. While licensing transactions are theoretically carried out between the individual user and the copyright owner, the Fox Agency-by virtue of its broad client base and the extensive authority it receives-is effectively able to set licensmg fees for the entire industry. Parties are spared the costs of gathering information regarding performances and translating such information into a negotiated price. The Fox Agency's control over those performance rights markets from

39. Of course, a more direct solution to the problem of monopsony power would involve breaking up the monopsonist, in this case the networks. However, performing rights organizations shonld not be viewed as a solution to the problem of network monopsony power; rather ASCAP's bargaining leverage shonld be viewed as an advantage favoring blanket licensing. In other contexts, problems of unequal bargaining power have been solved by allowing workers to forn labor unions exempt from antitrust hability. ASCAP can be viewed as a labor union for composers, providing some form of marketing leverage against users of copyrighted music.

40. The need for such a collective organization to combat the monopsony power of major users was recognized by the European Economic Commission in a decision concerning Gesellschaft für musikalische Auffuhrungs- und mechanische Vervielfaltigungsrechte (GEMA), the German performing rights organization. The Commission noted that "some exploiters of musical material ... [private radio and television broadcasters] oceupy such a strong position on the market that it enables them completely to control authors and composers . . . Collectimg society membership is . . necessary in relation to . . . broadcasting rights, where copyright holders are up against powerful users of music . . . " Commission Decision (82/204/EEC) of Dec. 4, 1981, relating to a proceeding under Article 86 of the EEC Treaty (IV/29.971-GEMA statutes), 25 O.J. Eur. CoMm. (No. L 94) 12, 17 (1982), [1982] 2 Common Mkt. L.R. (CCH) 482, 491, reprinted in [New Developments] COMMON MKT. REP. (CCH) I 10,357, at 10,771-14 (1982).

The potential abuse of monopsony power by television networks in this country was recognized by the district court in $C B S$ v. $A S C A P$. A publishing company executive testified that if publishers were to license perforinance rights directly to television networks, "there would be a deluge of price-cutting bordering on the cutthroat nature that would lead to mutual self-annihilation." 400 F. Supp. at 767.

41. See infra text accompanying notes 116-22.

42. Copyright owners usually assign the rights in their works to publishing companies which in turn distribute a portion of licensing revenues back to the original owner.

43. A synchronization right is the right to record copyrighted music on the soundtrack of a taped or filmed production. 
which ASCAP and BMI have been barred strongly suggests that some fcrm of collective hicensing is the most efficient and effective means of permitting copyright owners and users to take maximum advantage of statutory performance rights. ${ }^{44}$

\section{III \\ ENFORCEMENT OF ANTITRUST LEGISLATION}

While blanket licensing may be crucial for the effective exploitation of statutory copyrights, the virtual inonopoly power it extends ASCAP and BMI to issue performance rights licenses inay give rise to substantial abuse. ASCAP and BMI can exploit their bargaining advantage to insist that licensees remit excessive fees to acquire the riglit to perform any of the music in the societies' repertories. Accordingly, both the Government and private licensee groups liave challenged blanket licensing under the antitrust laws, resulting in two major constraints upon ASCAP's and BMI's operations. First, the government antitrust actions have resulted in negotiated consent decrees that preserve the practice of blanket licensing but subject ASCAP and BMI to continual judicial supervision. ${ }^{45}$ Second, as the result of actions brought by private user groups, ASCAP and BMI have been enjomed altogether froin issuing blanket licenses to selected groups of inusic users. Blanket licensing has been struck down for motion picture theater owners and for local television broadcasters, but upheld for radio broadcasters and television networks. ${ }^{46}$

\section{A. The Consent Decrees}

In 1941, the Justice Department challenged the blanket licenses offered by both ASCAP ${ }^{47}$ and $\mathrm{BMI}^{48}$ as illegal restraints of trade, alleging that both organizations were able to impose arbitrary prices for

44. In Buffalo Broadcasting Co. v. ASCAP, 546 F. Supp. 274, 293-96 (S.D.N.Y. 1982), the court, while acknowledging the cost advantages of blanket licensing, found them to be less compelling in the context of licensing non-network television performance rights because of the feasibility of source licensing. See infra note 93 . While source licensing may obviate part of the transaction cost rationale for blanket licensing because producers could obtain performing rights licenses at the same time synchronization licenses are negotiated, the parties would still incur substantial expense in estimating the value of their performing rights for a given use and exchanging such information with motion picture producers. More importantly, source licensing would not eliminate the need for a copyright owner to momitor a local station's programming to detect unauthorized performances of his inusic. In addition, the court paid insufficient atteution to the transaction time cost savings for live or unplanned performances of music.

45. See infra Section A of Part III.

46. See infra Section B of Part III.

47. Umited States v. ASCAP, 1940-1943 Trade Cas. (CCH) I 56,104 (S.D.N.Y. 1941), amended, 1950-1951 Trade Cas. (CCH) I 62,595 (S.D.N.Y. 1950).

48. United States v. BMI, 1966 Trade Cas. (CCH) I 71,941 (S.D.N.Y. 1966); United States v. BMI, 1940-1943 Trade Cas. (CCH) II 56,096 (E.D. Wis. 1941). 
their hicenses through unlawful copyright pooling. Cases against both societies were resolved through the issuance of negotiated consent decrees. Subject to certain modifications made in subsequent anendments, these decrees continue to govern the operations of both organizations.

The ASCAP decree, originally entered into in $1941^{49}$ and amended in $1950,{ }^{50}$ was designed to limit ASCAP's market power under blanket licensmg in several ways. Before 1941, users were unable to obtain licenses directly from ASCAP meinbers, but were required to obtain performance rights froin ASCAP under blanket licenses. The 1941 decree required ASCAP to offer per-program licenses ${ }^{51}$ in addition to blanket licenses, and permitted ASCAP to license its members' counpositions only on a nonexclusive basis. Individual ASCAP meinbers thus retamed the right to independently issue performance licenses for their own compositions. ${ }^{52}$ However, ASCAP was nevertlieless still able to exploit its market power by offering per-program licenses at unfair rates and by requiring its inembers to remit all self-negotiated licensing royalties to ASCAP for distribution among the general membership. Concern over this potential exploitation prompted the 1950 annendments to the consent decrees that required ASCAP to offer per-prograin hicenses at competitive rates ${ }^{53}$ and enjoined it from interfering with direct licensing by meinber composers..$^{54}$

By assuring both direct and per-program licensing as feasible alternatives to blanket licensing, these ainendments aimed to curb ASCAP's exploitation of its monopoly position under blanket licensing. ${ }^{55}$ Other provisions of the amended decree were similarly aimcd at

49. United States v. ASCAP, 1940-1943 Trade Cas. (CCH) I 56,104 (S.D.N.Y. 1941).

50. United States v. ASCAP, 1950-1951 Trade Cas. (CCH) I] 62,595 (S.D.N.Y. 1950).

51. United States v. ASCAP, 1940-1943 Trade Cas. (CCH) \ 56,104 (S.D.N.Y. 1941). Under a per-program license, a user receives access to all of the compositions in ASCAP's repertory in exchange for either a flat fee for each program in which ASCAP nusic is performed or a percentage of the advertismg revenues received from sucl programs. In either case, compensation is not based upon revenues fron programs which do not feature compositions in the ASCAP repertory or which contain music licensed directly from the copyright owner. Because ASCAP must carefully monitor all of the licensee's broadcasts (especially those not covered by the terms of the license) to detect infringements, the per-program license involves more extensivc reporting obligations than does blanket licensing. See Buffalo Broadcasting Co. v. ASCAP, 546 F. Supp. 274, 282 (S.D.N.Y. 1982).

52. United States v. ASCAP, 1940-1943 Trade Cas. (CCH) I 56,104, at 405 (S.D.N.Y. 1941).

53. United States v. ASCAP, 1950-1951 Trade Cas. (CCH) I 62,595, at 63,753-54 (S.D.N.Y. 1950). The requirenient that ASCAP offer a genuine economic clioice between a blanket or perprogram license was included primarily for the benefit of those broadcasters with relatively fcw commercial announcements and a greater percentage of sustained programming.

54. Id. at 63,752 .

55. Gamer, United States v. ASCAP: The Licensing Provisions of the Amended Final Judgment of 1950, 23 Bull. CopYright Soc'y 119, 124 (1976). Despite the issuance of the amendments, neither per-program nor source licensing lias been extensively pursued as an alternative to 
limiting ASCAP's market power. The decree restrained ASCAP from issuing blanket licenses for terms of inore than five years, ${ }^{56}$ and froin discriminating in licensing terms between users similarly situated. ${ }^{57}$ Users were given recourse to the District Court for the Soutliern District of New York for a determination of a reasonable fee if they objected to the one offered by ASCAP. ${ }^{58}$ However, although the amended decree substantially reduced ASCAP's market power to issue performance licenses, it did not disturb the practice of blanket licensing itself. ASCAP was not required to issue nonblanket licenses covering only portions of its repertory. ${ }^{59}$ In fact, ASCAP may license individual compositions only if the copyright owner has been notified of the applicant's request and lias agreed to the individual license. ${ }^{60}$

BMI's consent decree, originally entered imto in $1941^{61}$ and amended in $1966,{ }^{62}$ imposes conditions similar to those governing ASCAP, but with two important exceptions. First, BMI is not enjoined

blanket licensing, except in those markets where courts have prohibited ASCAP from issuing blanket bicenses. Id. at 138; Buffalo Broadcasting Co. v. ASCAP, 546 F. Supp. 274, 288 (S.D.N.Y. 1982).

56. United States v. ASCAP, 1950-1951 Trade Cas. (CCH) I 62,595, at 63,752 (S.D.N.Y. 1950).

57. Id. Discrimination between licensees did not enconipass differences based upon applicable business factors which justified different licensing terms. Garner, supra note 55, at 124. Prior to the decree, ASCAP had exploited its market power by withholding portions of its repertory to exact higher fees from users.

58. Garner, supra note 55, at 119,126 . Users were permitted to use any music covered by their pending applications until a reasonable fee could be determined. While applicants have invoked the ratesetting authority of the Southern District on a number of occasions, the court has never reached the nierits of such a request. Rather, the parties have always been able to agree on a proper fee through private negotiations subsequently approved by the court. Id. at 127-28. The court's power to dictate hicense terms probably encourages both users and ASCAP to act reasonably in negotiating blanket licensing fees. Id. at 149.

59. Because the 1950 decree allowed potential licensees to make written requests to ASCAP for use of "any, some or all of the compositions in the ASCAP repertory," United States v. ASCAP, 1950-1951 Trade Cas. (CCH) \ 62,595, at 63,754, and authorized the court to determine reasonable fees pursuant to such requests, broadcasters have contended that ASCAP was required under the decree to grant licenses not expressly authorized by its terms (i.e., other than blanket or per-program licenses). Such claims have been rejected by the courts. See, e.g., United States v. ASCAP (In re Application of Shenandoah Valley Broadcasting, Inc.), 331 F.2d 117 (2d Cir. 1964), cert. denied, 377 U.S. 997 (1974) (Southern District's fee-setting authority is concerned only with how fees are to be set for hicenses ASCAP is required to grant under terms of decree).

60. United States v. ASCAP (In re Application of NBC), 1971 Trade Cas. (CCH) I 73,491 (S.D.N.Y. 1970). In both Shenandoah Valley and NBC, the respective applicants had petitioned the court for hicenses based upon the nature of their uses and number of performances broadcast. It is not clear how such per-use licenses would by themselves check abuses of ASCAP's nonopoly power. While hicensing fees would presumably reflect actual uses of music, such fees would still be influenced by ASCAP's ability to withhold portions of its repertory to exact higher prices and by its purported ability to fix prices.

61. United States v. BMI, 1940-1943 Trade Cas. (CCH) If 56,096, at 382 (E.D. Wis. 1941).

62. United States v. BMI, 1966 Trade Cas. (CCH) I 71,941 (S.D.N.Y. 1966). 
from obtaining exclusive licensimg authority from its affiliates. ${ }^{63}$ Second, BMI licensees must resort to arbitration procedures rather than judicial determinations of reasonable blanket licensing fees in the event of a licensing dispute. ${ }^{64}$.

\section{B. Private Antitrust Actions}

Notwithstanding two decades of governmental regulation of performing rights societies through the enforcement of the consent decrees, certain groups of licensees remained dissatisfied. Several of these groups initiated private antitrust actions challenging ASCAP's anticompetitive practice of issuing single-fee blanket licenses. These private actions upheld blanket licensing for certain groups of users (radio broadcasters, television networks) but not for others (notion picture exhibitors, local television broadcasters).

\section{Motion Picture Exhibitors}

In Alden-Rochelle, Inc. v. ASCAP, ${ }^{65}$ notion picture exhibitors contended that ASCAP's exclusive control over the performing rights to musical works prevented members from licensing such rights directly to either theater owners or movie producers and therefore coinpelled the exhibitors to obtam blanket licenses on ASCAP's terms. ${ }^{66}$ The court ruled that ASCAP represented an unlawful combimation in restraimt of trade because it had the power to fix prices and exclude potential competition. ${ }^{67}$ As a result of the court's ruling, ASCAP was prevented from issuing blanket motion picture performance licenses to motion picture exhibitors. ${ }^{68}$ Motion picture performance rights were thereafter licensed directly to motion picture producers by copyright owners. $^{69}$ Thus, motion picture exhibitors are currently exempt from

63. Id. at 83,325 .

64. Id. at 83,325-26.

65. 80 F. Supp. 888 (S.D.N.Y. 1948).

66. ASCAP's cxclusive right to license performing rights was reinforced by contractual provisions between motion picture distributors and exhibitors requiring theaters to have ASCAP hicenses in order to exhibit films containing members' music. Id. at 894.

67. Id.

68. Id. at 903. The court restrained ASCAP from enforcing the motion picture performance rights of its members' musical compositious so long as it continued as an illegal combination and monopoly. In additiou, its members were prohibited from enforcing motion picture performance rights of compositions for whicl synchronization rights had been granted to motion picture producers. These provisions were subsequeutly imcorporated into the 1950 consent decree under which ASCAP operates. See United States v. ASCAP, 1950-1951 Trade Cas. (CCH) ๆ 62,595, at 63,752 (S.D.N.Y. 1950).

69. The bulk of motion picture performance rights licenses are exchanged through the Harry Fox Agency, which represents most copyright owners in such transactions. See infra text accompanying notes $116-22$. 
having to obtain blanket performance licenses in order to perform copyrighted works.

\section{Radio Broadcasters}

In $K$-91, Inc. v. Gershwin Publishing Corp. ${ }^{70}$ several ASCAP neinbers sued a Seattle radio station for copyright infringeinent. In defense, the station contended that the plaintiffs had misused their copyrights because ASCAP was an illegal combination engaging in price fixing in violation of the Sherman Act. ${ }^{71}$ The Nintle Circuit affirmed the lower court's conclusion that ASCAP was not operating as a combimation to restrain trade or as a monopoly because the 1950 consent decree prohibited it from engaging in activities that would violate the antitrust laws. ${ }^{72}$ Because all applicants had the riglit to have the District Court for the Southern District of New York set a reasonable fee whenever they believed the rates proposed by ASCAP to be unfair, with ASCAP having the burden of proving the price reasonable, the court ruled that ASCAP was not guilty of price fixing. Further, because the decree provided that ASCAP's hicensing authority was not to be exclusive, the court lield that the rights of mdividual copyright owners and licensees to make their own nonblanket licensing arrangements had been preserved. ${ }^{73}$ In the court's view, the decree had "disinfected" ASCAP as a potential coinbination in restraint of trade. So long as it complied with the provisions of the consent decree, ASCAP's practices would not fall within the purview of antitrust prohibitions with respect to the radio broadcast industry. ${ }^{74}$

\section{Television Networks}

In $C B S$ v. $A S C A P,{ }^{75}$ a television network souglt to enjoin the practice of blanket licensing as an unlawful restraimt of trade under the Sherman Act. CBS alleged that ASCAP used its market leverage to insist that CBS pay royalties for music it did not wisl to license, ${ }^{76}$ and sought to have ASCAP either enjoined from issuing network performance licenses, or alternatively, to require ASCAP to charge predetermined sums for each perfomance of copyrighted nnusic. ${ }^{77}$ The District Court for the Southern District of New York held that CBS had not

70. 372 F.2d 1 (9th Cir. 1967).

71. Id. at 2.

72. Id. at 4.

73. Id.

74. Id.

75. 400 F. Supp. 737 (S.D.N.Y. 1975), rev'd, 562 F.2d 130 (2d Cir. 1977), rev'd sub nom. BMI v. CBS, 441 U.S. 1 (1979).

76. $400 \mathrm{~F}$. Supp. at 745.

77. Id. at 741 . 
met its burden of proving that ASCAP had illegally compelled it to accept a blanket hicense. ${ }^{78}$ The court ruled that CBS had failed to demonstrate that the direct hicensimg permitted under the consent decree was not a viable alternative to blanket licensing. ${ }^{79}$

The Court of Appeals for the Second Circuit reversed, holding that ASCAP's blanket license was a per se violation of the Sherman Act. ${ }^{80}$ Blanket hicensing constituted illegal price fixing, the court reasoned, because it set one price for all musical compositions and thereby eliminated all price competition among ASCAP meinbers. ${ }^{81}$

The Supreme Court reversed the appellate court's ruling that the blanket license was a per se violation of the Sherman Act. ${ }^{82}$ The Court distinguished the price fixing at issue from the horizontal arrangements traditionally labeled per se violations. ${ }^{83}$ The Court emphasized that all three branches of Government had examined blanket licensing and had acknowledged its utility ${ }^{84}$ After concluding that the unique mar-

78. Id. at 779 .

79. Id. The court also noted that the lawsuit followed a breakdown in negotiations for a renewal by CBS of its blanket license from BMI and concluded that CBS lrad "sought a legal solution to what is essentialiy a business problem." Id.

80. $562 \mathrm{~F} .2 \mathrm{~d}$ at 140 .

81. Id. at 136. However, the court qualified its condemnation of the blanket license in two important ways. First, it found that the difficulty of individually licensing performing rights sometimes compelled a finding that price fixing under the blanket license was lawful. While the blanket license was a "market necessity" for radio broadcasters and therefore tolerable despite its price-fixing implications, the existence of an alternative system of direct licensing for network television performing rights meant that blanket licensing in this context did not meet the requirements for this "market necessity" exception. Id. at 137-38. Moreover, rather than enjoining ASCAP from the "illegal" practice of blanket licensing television network performance rights altogether, the court remanded the case to the district court with instructions to fashion a remedy ensuring that the blanket license would not affect direct licensing practices. Id. at 140 .

82. 441 U.S. at 2.

83. The Court found that the blanket license constituted not a simple lorizontal arrangement between copyright owners, but a different product "of which the individual compositions are raw material." Id. at 21-22. The court also noted that the "individual composers and autliors have neither agreed not to sell individually in any other inarket nor use the blanket license to mask price fixing in sucl other markets." Id. at 23-24.

84. Under the 1950 consent decree, both the executive and judiciary lad serutinized blanket licensing, imposed restrictions upon its use, and stood ready to provide further remedies agaimst anticompetitive practices. The Justice Department lad also specifically endorsed the need for " 'some kind of central licensing agency by which copyright holders may offer their works in a common pool" "in an amicus brief submitted in the $K-91$ case. See BMI v. CBS, 441 U.S. 1,14 (1979) (quoting Memorandum for Uınted States as Amicus Curiae on Petition for Writ of Certiorari at 10-11, K-91, Inc. v. Gersliwin Publishing Corp., 389 U.S. 1045 (1968) (No. 67-147)). The brief concluded that blanket licenses to individual radio stations were neither a per se violation of the Sherman Act nor an unreasonable restraint of trade. Id. at 15. The amicus brief submitted by the Justice Department in $B M I$ y. $C B S$ similarly indicated that the blanket license was not a per se violation of the Sherman Act in the context of network television. Id. Fimally, Congress lad cliosen to enact compulsory licensing for performances of copyrighted music by secondary cable transmission systems and jukeboxes, specifically exempting ASCAP from antitrust liability for these purposes. Id. at $15-16$ (citing 17 U.S.C. app. $\$ \$ 111$ (d)(5)(A), 116(c)(4), 118(b) (1982)). 
ket conditions of musical performing rights necessitated blanket licensing, ${ }^{85}$ the Court remanded the case to the court of appeals for a determination of whether blanket licensing represented an unreasonable restraint of trade under the Sherman Act. On remand, ${ }^{86}$ the Second Circuit found that blanket licensing survived the rule of reason standard $^{87}$ announeed by the Supreme Court. Customer preference for blanket licenses rather than such licenses themselves was held responsible for any restraint upon potential competition among compositions. ${ }^{88}$

\section{Local Television Broadcasters}

In Buffalo Broadcasting Co. v. ASCAP, the most recent challenge to the legality of blanket licensing, the court struck down the blanket hicensing of performance rights to local television broadcasters under a two-part rule of reason analysis. First, the court distinguished $C B S$ by noting that, unlike the networks, local television stations did not have the inarket power to compel either direct licensing of performing rights by copyright owners on an individual basis, or source licensing ${ }^{89}$ of such rights by motion picture producers. ${ }^{90}$ The absence of realistic nnarketing alternatives or potential competition outside the blanket license indicated that it was the blanket license itself rather than customer preference for that license that restrained competition for the bicensing of performing rights. ${ }^{11}$

Second, the court concluded that the blanket license unreasonably

85. After emphasizing the impracticability and expense mvolved in setting up an intricate schedule of fees and uses for individual compositions, conducting individual sales transactions and momitoring, and policing all users to detect infringements, the Court concluded that the blanket license "accompanies the integration of sales, monitoring, and enforceinent [of performing rights] against unauthorized copyright use." Id. at 20. The Court reasoned that to declare marketing arrangements reasonably necessary to effectuate the rights granted to copyright owners under the 1976 Copyright Act to be per se violations of the Sherman Act would severely constrain the commerce anticipated by the former and protected by the latter for the licensing of performing rights. Id. at 19.

86. $620 \mathrm{~F} .2 \mathrm{~d}$ at 930 .

87. Under the rule of reason standard for antitrust liability, a court will condemn a contract, combimation or conspiracy whose purpose or likely effect is to significantly restrict conpetition. In inaking such determinations, courts must look to both the adverse and beneficial effects of the practice involved and determine, on balance, whether the "restriction imposed substantially impedes competition." L. SUlLIVAN, HANDBOOK OF THE LAW OF ANTITRUST § 68, at 188 (1977).

88. 620 F.2d at 935 .

89. The tern "source licensing" refers to the practice of motion picture producers to license performing rights directly from copyright owners at the same time synchronization rights are secured. Under the Alden-Rochelle decision, the hicensing of theatrical motion picture performing rights takes place at the "source." However, the niotion picture producer does not seek a license for subsequent television performances.

90. 546 F. Supp. at 290, 292-93. The court also found the per-progran license, which the 1950 consent decree required ASCAP to offer at competitive rates, to be an unrealistic alternative because of high costs and onerous reporting requirements. Id. at 289.

91. Id. at 293. 
restrained the licensing of music performing rights to local broadcasters because its procompetitive advantages were outweighed by its anticompetitive effects. ${ }^{92}$ The court found that nnany of the acknowledged advantages of the blanket license were not applicable to the context of non-network television. ${ }^{93}$ Against this, the court noted that the blanket license "prevents price competition between and ainong the pooled compositions" and that "[r]ealistic [licensing] alternatives offering potential competition and consequent price restraint do not exist."94 The court enjoined ASCAP from continuing to issue blanket licenses to local broadcasters in order to effect the licensing of non-network television performing rights at the source, where individual negotiations between producers and copyright owners for synchronization and performing riglits would encourage price competition between musical compositions. ${ }^{95}$ The court's findings were restricted to the context of non-network television performing rights sucl that the blanket license presumably remains legal vis-a-vis other users of copyrighted music. ${ }^{96}$ Thus, under the rule of reason analysis announced in $C B S$ and applied in Buffalo Broadcasting, it appears that a court can prohibit blanket licensing where it finds that doing so would promote price competition between composers for the licensing of perforinance rights.

92. Id. at 296.

93. The court examined four of the acknowledged advantages of blanket licensing in the context of local television broadcasters. First, it found the blanket license's transaction cost savings to be negligible because the performance rights for most of the stations' programming could be licensed at the source when the producer negotiated for other music rights, witlout significant complications or increases im transaction costs. The court also acknowlcdgcd that the blanket license resulted in transaction cost savings for live syndicated programming and locally produced programming, but found such programming (and the consequent cost savings) to be insignificant. Id. at 294-95. Second, the court found the elimination of monitoring costs under the blanket license to be irrelevant as source licensing itself eliminated the need for a monitoring systein to either distribute royalties or detect infringeinents. Id. at 295 . Third, the court found that because it was unlikely that the additional costs of obtaining music performing rights at the source would deter producers from producing motion pictures, the asserted benefit of the blanket license in reducing up front costs for producers was negligible. Id. Finally, the court found that the flexibility offered to users under the blanket license was unimportant because the vast majority of thc broadcasters' programming used preplanned music. The court considered any constraints in the use of music in hive syndicated programming, locally produced programming, or for unplanned performances such as concerts or parades resulting from sucl loss of flexibility to be insigniflcant. Id. at $295-96$.

94. Id. at 293.

95. Id. at 296.

96. BMI is also prohibited from issuing blanket performance licenses to motion picture exhibitors and local television stations pursuant to the Alden-Rochelle and Buffalo Broadcasting decisions, respectively. 


\section{IV}

\section{THE INAPPROPRIATENESS OF ANTITRUST REgulation OF PERForming Rights SOCIETIES}

Without some supervismg authority, ASCAP could exploit its monopoly powers under blanket hicensing to force users to accept unreasonable licensing conditions or to effectively preclude them from using any of the music in ASCAP's repertory. Regulation of performing rights societies through application of the antitrust laws, however, is meffective in restraining such abuses. Dissatisfied users are compelled either to challenge the entire practice of blanket licensing or to rely on judicial enforcement of consent decrees limitimg ASCAP's and BMI's unfair marketmg practices. Both courses of action fail to control abuses of monopoly bargaining power.

Antitrust litigation is generally expensive, uncertain, and time consuming. Courts often cannot impose the remedies best suited to the goal of regulation-controlling abuses of market power. Antitrust enforcement is also constrained by the inability of the judiciary to enforce the remedies it imposes or to supervise performing rights societies adequately. These factors severely limit the effectiveness of both private antitrust litigation and consent decree enforcement as mechanisins for controlling the bargaining power of ASCAP and BMI. The most critical problem with antitrust enforcement, however, is that the goal of such regulation, namely, the proinotion of reasonable rates through the introduction of price coinpetition, ${ }^{97}$ is inappropriate and misguided in a market where price seldoin affects the desirability of a coinposition.

\section{A. The Limitations of Antitrust Remedies}

\section{Private Antitrust Challenges}

Three factors operate to limit the effectiveness of private antitrust actions in preventing performing rights organizations frown abusing their monopoly powers. First, because antitrusi actions often involve extensive and expensive litigation, such recourse is limited to users who can afford it. The $C B S$ case, for example, took eleven years to litigate. Both defendant organizations incurred substantial litigation expenses as well as significant revenue losses. ${ }^{98}$

97. Though antitrust laws are often aimed at goals other than promoting price competition, courts have nonetheless used them as regulatory mechanisms to promote price competition for performance rights. See, e.g., Buffalo Broadcasting Co. v. ASCAP, 546 F. Supp. 274, 296 (S.D.N.Y. 1982).

98. From 1970 through 1980, CBS's kicense with ASCAP was frozen pending the outcome of the litigation and was only recently readjusted retroactively to account for inflation and the network's own revenue increases during that period. ABC's ASCAP license has also been frozen since 1976 and the parties have yet to agree upon proper retroactive adjustunents. See Umited 
Second, the thrust of antitrust regulation is weakened by the inability of the judiciary to frame appropriate reınedies. Successful antitrust challenges can prevent ASCAP and BMI only froin issuing blanket performance licenses and not necessarily from demanding unreasonable terms from users seeking to secure music performance licenses. Litigants who, because of transaction-cost advantages, may want to continue to license performance rights under blanket schemes but who nevertheless object to the terms under which such licenses are offered cannot secure relief pursuant to private antitrust actions. The inadequacy of the judicial remedy becomes apparent when the results of successful antitrust actions are considered: rather tlian compelling societies to issue blanket licenses at reasonable prices, courts exempt theater owners and local broadcasters from securing perforinance rights licenses altogether.

Third, antitrust enforcement creates inequities based upon the inconsistent application of antitrust laws by different courts. As discussed in the precedimg Part, contradictory decisions liave been rendered in antitrust challenges by different groups. As a result of these disparate opinions, select groups of users need not secure performance rights licenses. Unsuccessful litigants, however, must continue to secure blanket licenses, relying only on the consent decrees to control abuses of monopoly powers. ${ }^{99}$

\section{Enforcement of Consent Decrees}

The provisions of the consent decrees strive to provide an alternative to antitrust litigation for those dissatisfied with the licensing fees set by a performing rights society. However, the provisions are unavailable to most users as protections against the market power of ASCAP and BMI.

Although users who are dissatisfied with ASCAP's blanket licensing fees inay apply to the District Court for the Southern District of New York for determinations of reasonable fees, ${ }^{100}$ judicial fee determinations can often involve the saine expense, delay, and frustration that plague private antitrust actions and that discourage all but the

States v. ASCAP, 1981-1983 Copyright L. Dec. (CCH) q 25,401, at 17,314 (S.D.N.Y. 1982). BMl's license with CBS was frozen in 1972 pursuant to the pending litigation and was adjusted upward to reflect inflation and CBS's increased revenues only in 1980 and not on a retroactivc basis. CBS v. ASCAP, 483 F. Supp. 616 (S.D.N.Y. 1980).

99. Because certain groups of users in this country are exempt from blanket licensing, fiscal difficulties between ASCAP and foreign performing rights organizations liave emerged. For example, one commentator notes that ASCAP's inability to collect fees for motion picture performances in American theaters has created an "imbalance. . . between ASCAP and its sister societies in Europe which has proved, and continues to prove, a source of friction." Wallace, Control over the Monopoly Exercise of Copyright, 4 INT'L REv. Indus. Prop. \& CopYruoHT L. 380, 381 (1973).

100. See supra note 58 and accoinpanying text. 
largest and most persistent users. ${ }^{101}$ There are also similar concerns with having disparate decisions rendered by different judges of varying experience and expertise. The cost and uncertainty associated with judicial fee setting seems to have discouraged parties from imvoking such remedial powers. The Southern District, for example, has never had to inake a final determination of what constitutes a reasonable blanket licensing fee. ${ }^{102}$ Moreover, the court's jurisdiction is strictly limited ${ }^{103}$ and does not extend to users who object to licensing conditions other than the fees exacted or who wish to have a reasonable fee determined for a nonblanket license.

While under both consent decrees, users inay either obtam perprograin licenses from ASCAP and BMI, ${ }^{104}$ or license performance rights directly froin the copyright owner, ${ }^{105}$ the transaction, enforceinent, and cost advantages of blanket hicensing make these alternatives unattractive. ${ }^{106}$ No provision is made in the decrees for judicial control of the prices charged for such licenses, ${ }^{107}$ and it is unclear that the judiciary would be capable of conducting such supervision even if given the necessary authority. As a result, the bulk of nondramatic theatrical inusic performance rights continue to be licensed under blanket schemes. ${ }^{108}$

The decrees also include specific conditions with which ASCAP and BMI must coinply when issuing blanket hicenses, but which are nevertheless difficult to enforce. For example, ASCAP is prohibited from discriminating against similarly situated licensees when issuing blanket licenses. ${ }^{109}$ Since private litigants are considered nonparties to

101. For example, in proceedings initiated by $A B C$ and ASCAP to fix an interim license fee pursuant to the amended final judgment in $C B S$, the court noted that the "supplemental papers submitted to this court have been voluminous and in some instances of doubtful relevance." United States v. ASCAP, 1981-1983 Copyright L. Dec. (CCH) I 25,401, at 17,315 (S.D.N.Y. 1982). While the court did set interim licensing fees pursuant to an amended final judgment, it lias yet to make a determination of a reasonable fee pursuant to its authority under the 1950 Consent Decree. Thus, resort to the judiciary for determinations of reasonable fees would seem to involve considerable amounts of time and expense.

102. Garner, supra note 55, at 127-28.

103. See supra note 59.

104. See supra note 53.

105. See supra note 54.

106. In addition, neither individual nor per-program licensing sclemes prevent copyright owners from collectively exploiting their market power. Individual licensing would ouly facilitate the transfer of ASCAP's market power to the Fox Agency or a comparable organization. See infra text accompanying notes 116-22. Under per-program licensing, ASCAP would still be able to withhold the licensing of its repertory to exact unreasonable fees.

107. Despite the decree's provisions that per-program licenses must be offered at rates whicl give licensces a genume economic choice, the Buffalo Broadcasting court found per-program licensing fees to be seven times higher than those for blanket licenses. 546 F. Supp. at 289.

108. See supra note 55 .

109. See supra note 57 . 
the consent decrees, a licensee claiming to be similarly situated to another must rely on the judiciary or the Government to enforce this provision. As an institutional body, the judiciary does not have the capacity to supervise performing rights organizations continually in order to ensure compliance with decree provisions. As a result of all these factors, enforcement of the consent decrees is at best a limited mechanism for protecting users against abuses of monopoly powers by performing rights societies.

\section{B. Price Competition in the Performing Rights Market}

The most fundamental problem with antitrust regulation of performing rights societies is that the aim of such regulation-the introduction of price competition into the performing rights marketplaceis sorely misplaced. Price competition is ordinarily not a significant factor im the performing rights market, not because the monopoly of ASCAP and BMI on the market prevents competitive prices from emerging, but instead because price seldom affects a user's selection of a musical composition. As a result, artificial atteinpts to inject competition into the performing rights marketplace are unlikely to ensure that users can secure performance rights at reasonable costs.

Price differentials are unlikely to have a significant effect upon a purchaser's selection of music because of the unique quality of each musical composition or recording and because each listener exercises his esthetic preferences. ${ }^{110}$ To a large degree, the user is attracted by the composer's nanie or the quality of the song, so that price considerations become secondary. Thus, within a wide range of prices, demand is relatively imelastic. At the sanie time, composers are unlikely to press for the highest performance fees they conceivably could earn. Composers are eager to license performances of their music, because public performances stimulate the more lucrative sales of plonograph records, prerecorded tapes, and sheet inusic, as well as interest in other such performances. ${ }^{111}$ These factors significantly reduce the effect of price on the selection of copyrighted inusic. ${ }^{12}$

110. One commentator has noted:

There may also be some reason to suspect that neither music users nor copyright owners will act as economic men in the licensing of performing rights. Whether price differential will play [a] significant . . . role in the competitive climate of inusic licensing ... remains to be seen. Valuation is, of course, much easier in the homogenous commodity context where there is no reason to prefer one producer's oil, for example, to another's. But the listener's aesthetic preference or the composer's eagerness to have his work performed inevitably injects an element of irrationality into what is already an unpredictable market.

Case Comment, CBS v. ASCAP: Who Calls the Tune? Performing Right Societies and the Rule Against Price Fixing, 31 Rutgers L. Rev. 720, 757 (1978).

111. See infra note 128.

112. The analysis becomes even more complicated when one considers that the bargamed-for 
Price differentials wonld have only limited effects on a user's selection of music for other reasons. Many blanket hicensees, especially concert halls, nightclubs, and other proprietors of live music, have little or no control over the music that will be performed there. Users such as radio stations and bars, which do exercise sonie discretion over the type of inusic to be played, would not be inclined to select cheaper, less popular compositions and risk alienating listeners and patrons, as the hicense fces saved would be trivial in conparison to the advertising and sales revenue lost. Even in the motion picture performing rights inarket, where compositions are interchangeable to a greater extent, it is unlikely that music would be selected based upon the cost of performing rights rather than the quality of the coinposition. Performing rights fees are insignificant in relation to overall production costs. ${ }^{113}$ Directors, who generally select the music for a film, are less likely to be constrained by cost considerations than producers would be. ${ }^{14}$ It is even more improbable that theater owners or television broadcasters would select the inotion pictures they license from producers based upon the cost of the music contained in such features, as such costs are insignificant when coinpared to the amounts paid for the programming. In sum, the concept of price competition between separate compositions is foreign and inappropriate to a narket in which the selection of works to be performed is inore a function of the composition's quality and popularity than its price.

Current hicensing practices reflect the fact that price coinpetition would not significantly alter the preferences of users in negotiating for performance rights licenses. Those courts that have upheld challenges to the legality of the blanket license have envisioned a inarket where users select the works to be performed and the number of times they will perform them according to the price of the performance rights license for a given composition. For example, the Buffalo Broadcasting court assumed that the local television performing rights inarket upon

price of a performing right is limited by the parties' abilities to gather relevant information on popularity and demand. It is even more difficult to conceive of price competition between compositions considering such imperfect information.

113. For example, while a network may pay up to $\$ 200,000$ for a one-hour episode of a dramatic serial, performauce royalties for that program may amount to only $\$ 1500$. CBS, $400 \mathrm{~F}$. Supp. at 756.

The combined synchronization and performance rights license sells for between $\$ 250$ and $\$ 20,000$ per composition per picture. Cirace, supra note 23, at $295 \mathrm{n} .114$. The price for this type of license may increase so that the composition is less likely to be considered fungible. Producers willing to pay substantial amounts for rights to a given composition would be less willing to substitute another work.

114. While producers may be concerned with cost minimization, it is unlikely that they would allow such considerations to constrain a director's selection of music as the costs imvolved are likely to be insignificant. Moreover, major producers often act as their own distributors, and therefore pass production costs on to exhibitors. 
which it imposed the source licensing remedy was dominated by such price competition because the active negotiations between the parties hicensing the performance rights indicated that users were seeking the best product at the lowest price. ${ }^{15}$ However, the hicensing of motion picture theater performance rights, which pursuant to the AldenRochelle decision are secured directly from copyright owners, mdicates that neither composers nor users engage in significant economic bargaining when conducting such transactions.

The procedure for licensing motion picture performance rights usually begins when a producer contacts the Harry Fox Agency, expressing interest in licensing performance and synchronization rights to a musical work and providing information as to the use to be made of the coinposition. ${ }^{116}$ After contacting the publisher, the Fox Ageney quotes a price to the producer (almost always within two days), which is usually accepted (or rejected) on the spot. ${ }^{117}$ In some instances, the Agency is sufficiently familiar with the pubhisher's fee schedule so that contact with the publisher is not necessary for it to quote a price. ${ }^{118}$ Using a staff of two employees, the Fox Agency issues several thousand television synchronization and several hundred movie synchronization and performance hicenses annually. ${ }^{119}$ Hence, the procedure of hicensing motion picture theater performance rights reflects a simple quotation/acceptance transaction rather than the competitive price negotiations envisioned by the Buffalo Broadcasting court.

The simphicity of performing rights licensing is even more apparent when coinpared with the licensing transactions for television synchronization rights that are also brokered by the Fox Agency. The prices charged for licensing television synchronization rights are usually between $\$ 50$ and $\$ 150$ per composition, with some evidence that im many imstances this amount would be zero if not for "nuisance value." ${ }^{20}$ Despite the facts that prices for performing rights are considerably higher, that the Fox Agency generally has more contact with the publisher when quoting a motion picture performance-synchronization hicensing fee, and that the performance-synchronization license encoinpasses substantially inore variables, the district court in $C B S$ found synchronization and performance-synchronization rights transactions to be similarly uncomplicated. ${ }^{121}$ These clear-cut transactions
115. 546 F. Supp. at $283-84$.
116. $C B S, 400 \mathrm{~F}$. Supp. at 760 .
117. Id.
118. Id.
119. Id.
120. Cirace, supra note 23 , at 295 n.114.
121. 400 F. Supp. at 763 n.13. 
belie the "competitive negotiations" envisioned by the Buffalo Broadcasting court.

The power of the Fox Agency effectively to set a scliedule of licensing fees also indicates that price competition among musical coinpositions is not an important factor in negotiations for performance rights. The Buffalo Broadcasting court suggested that the anticompetitive blanket license could easily be replaced by competitive negotiations for music performing rights between copyright owners and producers of locally televised programming. However, these publisherproducer transactions generally do not take place on an individual level, but are brokered almost exclusively through the Fox Agency. Since the Fox Agency does not bargain with individual licensees over fees but inerely quotes prices for their subsequent acceptance or rejection, the licensing of performance rights at the source would not spur price competition for such commodities, but would inerely transfer the monopoly power from one organization (ASCAP or BMI) to another (Fox). ${ }^{122}$

Certain other features of the inotion picture performance rights market indicate that price competition is an ineffective ineans of regulating that market. Producers often engage "composers for hire" to score the background inusic for a film and arrange to have the copyright assigned to publishing companies which the producers control. ${ }^{123}$ Price competition among compositions is not likely to be a factor determining which coinpositions will be used in the score, since generally the inusic written is entirely original. Moreover, since the copyright to the score has been vested in the producer's publishing subsidiary, there are no negotiations over the value of the performance rights. ${ }^{124}$ With respect to works not inade "for hire," inany producers attempt to secure synchronization and performance rights only after the composition has been recorded onto film-again, price competition between compositions is unlikely to characterize the licensing process. ${ }^{125}$

While there is a need to regulate the activities of performing rights

122. The power of the Fox Agency to effectively set licensing fees might encourage dissatisfied users to challenge its operations under antitrust laws despite its agency capacity. Slould the Agency's operations be found to violate antitrust prohibitions, copyright owners and licensees would find it difficult to conduct individual licensing transactions for performance rights. Antitrust regulation of performing rights organizations depends on the existence of some organization like the Fox Agency to collectively license performance rights if ASCAP is enjomed from doing so.

123. $C B S, 400 \mathrm{~F}$. Supp. at 755-56. Any increase in transaction costs resulting from the elimination of blanket hicensing is also likely to cause motion picture prodncers to use the composer for hire more frequently, to the economic and professional detriment of current copyright owners.

124. Id. at 756 .

125. In sucli cases, producers rarely encounter dificulty in obtaining performing rights hicenses. Id. at 775-77. 
societies under blanket licensing to guard against unfair exploitation of bargaining power, this regulation should not be aimed, as some courts have suggested, at prounoting price counpetition for the licensing of performing rights. The Buffalo Broadcasting court correctly distinguished its case froin $C B S$ on the grounds that local television stations lacked the bargaining power the network enjoyed to compel ASCAP to act reasonably in negotiating blanket licenses, but incorrectly sought to promote price competition for the licensing of performance rights rather than take direct measures to correct this imbalance. ${ }^{126}$ The absence of price competition in the performing rights unarket nullifies any attempt to stimulate such coinpetition as a means of ensuring that users can hicense performance rights at reasonable rates. The experience of the Fox Agency imdicates that any ban of blanket licensing pursuant to antitrust enforcement is unlikely to lead to the price competition for performance rights that would provide users with relief against ASCAP's market power. In fact, in those markets where courts have chosen to ban ASCAP and its blanket license, its market power has inerely been transferred to the Fox Agency, which can effectively set licensing fees throughout the industry. ${ }^{127}$

Any ban of blanket licensing in response to successful antitrust litigation would eliminate the marketing and policy advantages of such practices which may be crucial to facilitate the licensing of public performance rights. Without the blanket license, transaction, enforceinent, and marketing costs might prohibit users froin licensing performance rights and deprive copyright owners of the full benefit of their statutory performance rights; users will either refrain from performing the works publicly or will perform them illegally. Copyright owners would be unable to detect such infrimgennents because of prohibitive transaction costs. Rather than sacrificing the acknowledged advantages of blanket hicensing in an awkward attempt to promote price competition, ${ }^{128}$ the regulation of performing rights organizations

126. The absence of price competition for performing rights also suggests that the Buffalo Broadcasting court wrongly struck down the blanket license for local television broadcasters as an anticompetitive restraint of trade. Certain features unique to the performing rights market, rather than the blanket license, are responsible for restraining price competiton for performing rights. In light of the advantages of blanket licensing in the local television performance rights market, the court should have allowed such practices to contimue.

127. Of course, it cannot be assunted that the Fox Agency will broker the hicensing of nonnetwork television performing rights pursuant to the Buffalo Broadcasting decision. However, the existence of the Fox Agency indicates that copyright owners are likely to have such rights collectively licensed by a single agency because of the marketing cost advantages.

128. It is imteresting to note that despite the absence of price competition under blanket licensing, the inarket for licensing inusic performances remains extremely competitive because of the value of public performances to copyright owners. In $C B S$, the district court noted:

Copyright proprietors are eager to have their music performed on television not simply to earn performance royalties distributed through ASCAP and BMI, but because 
should operate to preserve the practice of blanket licensing while ensuring that users have some protection against the monopoly powers of ASCAP and BMI.

\section{$\mathrm{V}$}

\section{An Alternative Agency Model}

If antitrust laws are not used to control the activities of performing rights societies, some other means of regulating these organizations must be devised that would both permit blanket licensing and curb monopolistic abuses. Rather than encouraging price competition, such regulation should instead focus on the relative bargaining power of performing rights societies and their licensees. Several commentators have suggested that the United States establish a regulatory agency to oversee the practices and fees set by performing rights societies, ${ }^{129}$ as other Western nations have done. ${ }^{130}$ This Part describes the agencies that the United Kingdoin and West Gernany have established to regulate their respective performing rights societies. ${ }^{131}$ It will be argued that if the Uinted States were to establish an agency coinparable to those in the United Kingdoin and West Germany, such an agency would possess distinct advantages over antitrust enforceinent.

\section{A. The United Kingdom}

In the United Kingdom, blanket licenses authorizing public per-

a television performance before millions of viewers is the most effective way to sell phonograph records and sheet music, and to generate performances by other music users.

$400 \mathrm{~F}$. Supp. at 770 . Although the competition for performances in media other than network television may be less imtense because the potential rewards are less lucrative, there is every indication that composers and publishers direct extensive promotional efforts towards such users and that their markets are similarly competitive. There is "no indication that, should the blanket license be abandoned, competition in any but the most abstract sense would be the victor." Comment, CBS v. ASCAP: Who Calls the Tune? Performing Right Societies and the Rule Against Price Fixing, 31 RutGers L. REv. 720, 757 (1978).

129. See, e.g., Note, Blanket Licensing, supra note 18, at 749; Note, Performing Rights Societies, supra note 18 , at $802-03$.

130. See A. Dietz, Copyright LaW In the European Community 212-37 (1978). The licensing of music performance rights abroad is orchestrated by a single organization in each country in coutrast to the two which dominate heensing in the Umited States.

131. Other European nations also use administrative agencies to check potential abuses of monopoly power by performing rights organizations. For example, the Netherlands performing rights organization, Het Bureau voor Muziek-Auteursrecht (BUMA) is subject to permanent supervision by the Minister of Justice. The Minister, acting through a government commission, is required to consult with users of musical works in performing his snpervisory functions. Id. at 23437. In Italy, the monopoly over performing rights of the Societd Italiana degli Autori ed Editori (SIAE) is counterbalanced by a dual system of government supervision. Not only is SIAE subject to continuous supervision by the Presiding Committee of the Italian Society of Ministers, but its articles of association must be confirmed by a Presidential decree. Id. at 230-32. Even Luxembourg, which has no collecting societies of its own, subjects all such organizations operating within its borders to certain approval requirements. $I d$. at 232-34. 
formances of copyrighted musical works are issued by the Performing Rights Society (PRS) pursuant to authority granted by member copyright owners. ${ }^{132}$ Licensees or groups of users who are dissatisfied with PRS's fees or practices may apply to a Performing Rights Tribunal for review of the heenses offered. ${ }^{133}$ British copyright law provides for two procedures under which the Tribunal may determine the suitability of the hicenses. First, the Tribunal is empowered to review an entire licensing scheme ${ }^{134}$ under a procedure known as a "reference."135 The examination of a whole licensing scheme can be initiated by either a user imterested im obtaming that type of license or an organization representing a group of potential hicensees. ${ }^{136}$ The Tribunal may either confirm or amend the particular licensing scheme for a definite or indefinite period of tine..$^{137}$

Second, British copyright law allows users to challenge the suitability of mdividual hicenses within or outside a given scheme under a procedure known as an "apphcation." 138 In an application, a user may allege that PRS has refused to issue a hicense under a given scheme or that a license outside such a scheme has been unfairly withheld or offered only on unreasonable terms. ${ }^{139}$ As is the case with a "reference," outside organizations or persons with a substantial interest in the proceedings may be made parties. ${ }^{140}$ If the Tribunal is satisfied with the evidence presented, it will grant the license under the relevant scheme or upon reasonable terms. ${ }^{141}$

The cost of invoking either form of Tribunal review is nominal, and the Tribunal may compel one party to defray the expenses of another party when appropriate. ${ }^{142}$ The Tribunal's authority is most

132. The scope of the copyright owner's performing right under the Berne Convention (of which Great Britain is a member) is similar to that extended under American copyright law. Wallace, supra note 99, at 381. PRS issnes blanket performance licenses covering all of the compositions in its repertory to movie theaters, television and radio broadcasters, and other traditional users of copyrighted music. It is the only such licensing organization in the Umited Kingdom. A. DIETZ, supra note 130, at 227-30.

133. Copyright Act, 1956, 4 \& 5 Eliz. 2, ch. 74, \$§ 23-30. Under British law, the Tribunal's jurisdiction extends only to organizations which grant "general licenses, each extending to the works of several authors"-i.e., the blanket licenses issued by PRS. Id. \& 24(3). Performing rights hicenses issued on an individual basis are not subject to the Tribunal's authority. See Wallace, supra note 99, at 384.

134. Copyright Act, $1956,4 \& 5$ Eliz. 2 , ch. 74, $\$ 25(1)$. The tern "licensing scheme" refcrs to a general type of hicense offered by PRS to a class of licensees. Id. $\$ 24(4)$.

135. Id. $\$ 24(1)(\mathrm{a})$.

136. Id. $\$ 25(1)$.

137. Id. $\$ 25(5)-(6)$.

138. Id. $\$ 24(1)(\mathrm{b})$.

139. Id. \& 27(2)-(3).

140. Id. $\$ 27(4)$.

141. Id. \$ 27(5). See also A. DIETZ, supra note 130, at 227-28.

142. Wallace, supra note 99 , at 385 . 
commonly invoked in the context of a rate-fixing exercise after the user and PRS have failed to negotiate a licensing fee.

Because PRS operates as a virtual inonopoly over the licensing of 1nusic performance rights in the United Kingdom, historically it, like ASCAP and BMI, has been subject to substantial scrutiny for potential abuses of nuonopoly power. When PRS was originally established in 1875 , its accusations agamst infringers were countered by claims that PRS's operations represented an unlawful convbimation in restraint of trade. While courts generally absolved PRS of liability, the allegations drew the Government's attention. ${ }^{143}$ The British Government, however, chose to rely upon coinpulsory arbitration procedures rather than the enforcenent of antimonopoly laws to deal with potential abuses of PRS's inonopoly power. It recognized that "[i]f such an association is to function effectively, it must obtain as near a super-monopoly as is possible of the monopolies conferred upon composers." 144 The Performing Rights Tribunal and the "reference" and "application" procedures were deliberately established "to provide a possibility of correction in the event of abuse of the monopoly position by the collecting societies." 145 Consequently, challenges to the legality of blanket licensing under antimonopoly laws have not been pursued as a neans of regnlating PRS's operations.

Several commentators have compared the effectiveness of the Performing Rights Tribunal with that of antimonopoly laws in controlling potential abuses of PRS's market power. One commentator has concluded that while it is in the public interest to accept performing rights monopolies, "anti-cartel laws are too blunt an instrument to use to control [such] 1nonopol[ies]." 146 Regulation by the Performing Rights Tribunal, he observed, "on the whole . . . appears to work reasonably well."147 Another commentator has concluded that there is "nothing in the American experience . . . to deinonstrate . . . that the monopoly of the copyright societies is not in the public interest," and has recommended coinpulsory arbitration as an effective deterrent of inonopolistic abuses. ${ }^{148}$

143. G. McFarlane, Copyright: The Development and EXERCise of the Performing Right in Great Britain 161-62 (1980).

144. Id. at 162 (citing Select Comm. of the House of Commons, SPEClal Report on the Musical CopYright Bill (1930)).

145. A. DiETz, supra note 130, at 229.

146. Wallace, supra note 99 , at 382.

147. Id. at 386.

148. G. MCFARLANE, supro note 143, at 184-85. A final commentator has noted that while "[t] here is undeniably a great similarity with supervision procedures under cartel law for guarding against abuses of monopoly positions . . . it is still important . . that this special procedure . . . has been dealt with . . . within Copyright Law itself and has thus been given a special formula- 


\section{B. West Germany}

Of all Western nations, West Germany has developed the most comprehensive system to regulate performing rights societies. Under German law, ${ }^{149}$ any organization engaging in the joint exploitation of authors' rights is required to secure permission from the German Patent Office. Music performance rights are collcctively licensed on an author's behalf by an organization known as the Gesellschaft für musikalische Aufführungs- und mechanische Vervielfältigungsrechte (GEMA). ${ }^{150}$ The German Patent Office maintaims permanent supervision over GEMA, ${ }^{151}$ and can revoke the organization's operating permit if GEMA fails to meet its legal obligations. ${ }^{152}$

GEMA is obliged by law to license performance rights upon equitable terms to anyone upon request, ${ }^{153}$ to conclude blanket contracts on equitable terms with associations of users, ${ }^{154}$ and to establish scales of fees that allow for certain special interests. ${ }^{155}$ A special arbitration procedure has been established to resolve disputes in cases where GEMA is unable to conclude contracts with a user association or broadcasting company. ${ }^{156}$ All of these provisions are geared toward preventing abuse of GEMA's monopoly position vis-a-vis users. ${ }^{157}$

Moreover, unlike the antitrust laws of other European nations, German cartel legislation continues to play a substantial role in regulating the operations of performing rights organizations. The German Patent Office must consult with the German Federal Cartel Office when determining whether to grant or revoke a performing rights soci-

tion suited to the requirements of copyright . . . [which] would not have been possible . . . [under] cartel law alone." A. DieTZ, supra note 130, at 229-300.

149. Gesetz über die Wahrnehmung von Urheberrechten und verwandten Schutzrechten (Law on the Administration of Copyright and Related Rights), in 1965 BUNDESGESETzBLATT [BGBl], TeIL I (compilation of federal statutes and decrees) at 1294 (W. Ger.); see also A. DieTz, supra note 130 , at 219.

150. While GEMA is the only German organization hicensing music performing rights, the laws discussed below also govern the operations of other German collecting societies which enforce other aspects of an author's copyright. A. DIETZ, supra note 130, at 219-22.

151. Id. at 220.

152. Id. (citing Law on the Administration of Copyright and Related Rights, supra note 149, $\S 4,1965$ BGBl, Tell I at 1294).

153. Id. (citing Law on the Administration of Copyright and Related Rights, supra note 149, $\S 6,1965$ BGB1, Tell I at 1295).

154. Id. (citing Law on the Administration of Copyright and Related Rights, supra note 149, $\S 12,1965$ BGB1, TeIL I at 1295-96).

155. Id. (citing Law on the Administration of Copyright and Related Rights, supra note 149, $\S 13,1965$ BGBl, TeIL I at 1296).

156. Id. (citing Law on the Administration of Copyright and Related Rights, supra note 149, $\S 14,1965$ BGBl, TEIL. I at 1296).

157. Id. at 221. 
ety's permit. ${ }^{158}$ Although GEMA has been exempted from anticartel prohibitions, it remains subject to the Cartel Office's supervision to guard against abuses of the market power acquired by such exeinption. ${ }^{159}$ Thus, unlike the antitrust laws in the United States, which are used to challenge the legality of ASCAP and its licensmg practices, German anticartel laws provide the authority for an administrative body to oversee GEMA's operations and check specific abuses of its inonopoly powers. One commentator has termed this dual supervision under German law "excessive," and has said that the supervisory authority of the Patent Office is "quite sufficient" to combat any adverse effects of GEMA's de facto monopoly. ${ }^{160}$

While GEMA is exempt from the antitrust prohibitions of German law, the European Economic Commission, pursuant to its authority under the Treaty of Rone, successfully challenged GEMA's legality in 1971. ${ }^{161}$ The Commission alleged that because of GEMA's attempt to turn its dominant position over music licensing in West Germany into an absolute monopoly, competing societies could not survive. ${ }^{162}$ In the Commission's view, "GEMA confused the necessity for collective management of performing rights with manageinent by a smgle society which establishes and defends its exclusive position by improper ineans."163 It believed that GEMA menibers should be free to assign their performing rights to other societies (either foreign performing rights societies or other German authors' rights societies) and to decide whether to withhold the administration of certam categories of rights froin GEMA. ${ }^{164}$ These findings compelled GEMA to alter its constitution and to cease the offending practices. GEMA is still permitted to issue blanket performance licenses covering all of its inent-

158. Id. (citing Law on the Administration of Copyright and Related Rights, supra note 149, $\S 18(3), 1965 \mathrm{BGBl}$, TEIL I at 1297).

159. Gesetz gegen Wettbewerbsbeschränkungen (Law against Restraint of Competition) $\S 102(a)$, in 1974 BGBl, TEIL I at 895; see A. DIETZ, supra note 130, at 221.

160. See, e.g., A. Dietz, supra note 130, at 221.

161. Treaty establishing the European Economic Community (Treaty of Rome), Mar. 25, 1957, 1957 BGBl, TEIL II at 753, 298 U.N.T.S. 11. Article 86 prohibits an enterprise from exploiting in an improper manner a dommant position within a substantial part of the Common Market. Id. art. 86, $1957 \mathrm{BGBl}$, TEIL II at 826, 298 U.N.T.S. at 48-49. The Commission found (1) that GEMA was an enterprise within the meaning of article 86 ; (2) that it dominated music performance rights liceusing in West Germany, a substantial part of the Common Market; and (3) that it exploited this domimant position in an improper manner as discussed below. See G. MCFARLANE, supra note 143, at 179.

162. Id. at 179. More specifically, the Commission objected to GEMA's requirement that members assign it copyrights for all categories of works and for the whole world-requirements which were not "objectively justified" and which complicated the movement of its meinbers froin GEMA to other societies.

163. Id. (citing Commission Decision of June 2, 1971 (In re GEMA), 14 J.O. COMM. EuR. (No. L 134) 15 (1971), 1971 Common Mkt. L.R. (CCH) D35).

164. Id. at $180-81$. 
bers' compositions. ${ }^{165}$

Several authorities have severely criticized the GEMA decision, and the apphication of antimonopoly laws to the operations of performing rights societies in general. During the Commission's investigation of GEMA, the European Broadcasting Union coinplaimed to the Commission that "if coinpetition were to be artificially created in this sphere it would be to the detriment of broadcasting organizations which . . . would suffer consequences economically harmful to them." It suggested instead that the Commission "recommend to the governments concerned to insert provisions in their domestic legislations for the settimg up of a jurisdictional, arbitration, or ratifying body with powers . . . to determine the royalty payable by the broadcasting organizations to the society." 166

One commentator argued that if the result of the GEMA decision were carried to its logical conclusion, there might be a inultiplicity of collecting societies, each controlling within Gerınany or any other Community State the rights of different groups of authors. ${ }^{167}$ This would present a considerable impediment to the inusic user, who "would have to look up lists to see which society controlled the rights in the particular work he wished to use and whether he had the society's license to do so." 168

\section{The Advantages of Agency Regulation}

The primary advantage of agency regulation, as established both in the United Kingdoin and West Gernany, is that such authorities better balance the relative bargaining power of the parties to licensing transactions. Agencies provide an efficient and expedient inethod of resolving disputes concerning the fee or ternns of licenses that is accessible even to the smallest user. The power of the agency to arbitrate disagreements severely constrains the ability of the performing rights society to exploit the bargaining advantage it would otherwise enjoy. While similar recourse is theoretically available to users in this country under the provision in the 1950 consent decree authorizing the Southern District of New York to determine blanket licensing fees, and while there is some evidence that the court's power to set fees encourages both users and ASCAP to act reasonably in negotiating blanket licenses, the regulatory systems developed in other countries still possess distinct advantages.

165. Id. at 183 .

166. Wallace, supra note 132, at 382 (quoting Letter from the European Broadcasting Union to the Commission of the European Economic Community (June 4, 1969)).

167. Id. at 382.

168. Id. 
An administrative agency whose sole function is to set rates for music performing rights or to settle disputes between collecting societies and licensees is undoubtedly more expert than the judiciary to determine reasonable blanket licensing fees. ${ }^{169}$ In contrast to the expensive and frustrating litigation that would accompany a judicial fee determination, agency appeal procedures like those found in other nations presumably would foster expediency and reduce otherwise prohibitive costs. ${ }^{170}$ In contrast to the uncertainty engendered by the possibility of conflicting judicial determinations, a single agency would provide for greater consistency.

In addition, the authority of the Southern District under the decree extends only to determinations of reasonable blanket licensing fees. The court has been held not to possess the authority to order ASCAP to issue other types of licenses or to settle disputes over other terms. Moreover, private parties, considered nonparties to the agreement, are unable to charge that ASCAP's licensing practices violate the terms of the decree. ${ }^{171}$ In contrast, an administrative agency would be able to settle disputes as to licensing terms other than fees and to authorize alternative forms of licensing on an experimental basis to determine if there are certain contexts where blanket licensing would be less desirable. Fimally, the effectiveness of the consent decree as a means of equalizing bargaining power is undermined by the continuing threat of new, lengthy, and expensive private antitrust challenges to blanket licensing. For all of these reasons, an administrative agency is better suited than the judiciary to ensure that users obtain blanket licenses at reasonable rates.

For the United States to establisl1 a system of administrative regulation to guard against potential monopolistic abuses by ASCAP and BMI, Congress would first have to exempt performing rights organizations from antitrust liability. ASCAP and BMI could then issue blanket performance licenses to all users of copyrighted inusic without being restricted to those markets that withstand a rule of reason analysis. Congress would then need to cstablish an administrative agency to resolve licensing disputes between the organizations and their music licensees. Congress could even vest sucli authority in the Copyright Royalty Tribunal, which currently sets blanket performance licensing fees for certain groups of users. ${ }^{172}$ Because the Tribunal is already fa-

169. "[While] judicial fee-setting definitely influences fee negotiations, [its] nse as a dispute resolving mechanism . . . is questionable. The District Court for the Southern District of New York hardly possesses expertise in copyrights-licensing fees. Resort to the distriet court would in inost cases be the equivalent of litigation." Note, Blanket Licensing, supra note 18, at 749.

170. See supra text accompanying note 142.

171. See supra notes 59-60.

172. See Note, Blanket Licensing, supra note 18, at 749 . The Copyright Royalty Tribunal was 
miliar with setting licensing fees for performance rights and with gathermg information relevant to the determination of such fees, it seems well suited to the proposed task. Specific provision should be inade to promote the speedy resolution of licensing disputes and to avoid the other limitations associated with the judicial rate-setting authority provided for in the consent decree. The reinedy should be designed to discourage frivolous or dilatory claims, as well as intimidation tactics by the performing rights societies.

Finally, Congress might consider giving the new agency a general supervisory authority in addition to providing for the arbitration of licensing disputes. The agency might be given the power to issue and enforce licensing regulations similar to those contamed in the consent decrees. ${ }^{173}$ The agency might also be able to experiment with different forms of inusic licensing to meet exceptional needs. A systein of administrative regulation would introduce flexibility and fairness into the hicensing of performance rights without the delay, expense, and frustration accoinpanying antitrust enforcement.

\section{Conclusion}

While the blanket licensing of musical performing rights is crucial to their exploitation, history has demonstrated a definite need for some inechanism to prevent ASCAP and BMI from abusing their market power to exact unreasonable fees from licensees. The enforcement of antitrust legislation is at best an awkward device for balancing the bargaining power of performing rights societies and their licensees. Both private litigation and consent decree enforcement are unavailable to inany users as mechanisms for guarding against abuses of inonopoly power. More miportant, it makes hittle sense to use price competition as a regulatory mechanism smce price differentials rarely influence a user's selection of music. Such regulation does nothing to ensure that users can obtani performance licenses at reasonable rates since the inarket power of ASCAP and BMI is merely transferred to another organization like the Fox Agency. In contrast, the existence of a government agency to regulate the activities of performing rights societies would operate as a direct check against abuses of bargaining power by such organizations.

established under the Copyright Act of 1976 to set royalty rates for compulsory hicensing fees to be paid to copyright owners for mechanical rights, and for blanket performance rights for jukeboxes and secondary cable transmissions. 17 U.S.C. $\$ \$ 801-810$ (1982). Because its rate-setting functions differ from the arbitrative functions of the new agency this Comment proposes, the Tribunal should be vested with the latter authority only if separate provision is made for increased administrative capacity and expertise.

173. See supra notes $56-57$ and accompanying text. 
The effectiveness of agency regulation in preventing performing rights societies from issuing blanket licenses upon unfair terms is demonstrated by the experiences of other Western nations that have established such agency oversight. Given the caution usually associated with increased administrative regulation in any context, these systems would appear especially attractive as they retain the market as the primary meclianism for setting blanket licensing fees, with the government stepping in only to correct market imperfections caused by the performing riglits organizations' monopoly powers. Given the clear need to regulate performing rights societies, and the fact that antitrust laws are ill suited to this task, Congress should not liesitate to draw upon the resources of the Copyright Royalty Tribunal or to create a new regulatory agency. ${ }^{174}$ Agency regulation preserves the advantages of blanket hicensing, and appears better suited to securing performance rights for users at reasonable rates.

Jay M. Fujitani*

174. There are precedents for direct governmental involvement in setting prices for various rights in unusic in this country. For example, the Copyright Royalty Tribunal is vested with the authority to set royalty rates for coinpulsory license fees to be paid to copyright owners for mechanical rights in their music, and for blanket performing rights for jukeboxes and secondary cable transmissions. See supra note 172. More recently, the Register of Copyrights has proposed the creation of a performing right in sound recordings also subject to compulsory blanket licensing. See A. LATMAN \& R. GoRMAN, supra note 8, at 413-16. The acceptability of regulation of performing rights organizations by a governmental agency, as this Comment proposes, would appear to be foreshadowed by prior governmental involveinent in setting prices for music rights.

* B.A. 1981, University of California, Los Angeles; third-year student, School of Law (Boalt Hall), University of California, Berkeley. 